\title{
Assessing the importance of spectators to soccer clubs in South Africa: A management perspective
}

\begin{tabular}{|c|c|}
\hline \multicolumn{2}{|c|}{$\begin{array}{l}\text { Authors: } \\
\text { Victor S. Mogajane }{ }^{1} \\
\text { Engelina du Plessis }^{2} \\
\text { Elmarie Slabbert }\end{array}$} \\
\hline \multicolumn{2}{|c|}{$\begin{array}{l}\text { Affiliations: } \\
{ }^{1} \text { School of Tourism } \\
\text { Management, North-West } \\
\text { University, Potchefstroom, } \\
\text { South Africa }\end{array}$} \\
\hline \multicolumn{2}{|c|}{$\begin{array}{l}{ }^{2} \text { Tourism Research in } \\
\text { Economic Environs and } \\
\text { Society, School for Tourism } \\
\text { Management, North-West } \\
\text { University, Potchefstroom, } \\
\text { South Africa }\end{array}$} \\
\hline \multicolumn{2}{|c|}{$\begin{array}{l}\text { Corresponding author: } \\
\text { Engelina du Plessis, } \\
\text { lindie.duplessis@nwu.ac.za }\end{array}$} \\
\hline \multicolumn{2}{|c|}{$\begin{array}{l}\text { Dates: } \\
\text { Received: } 11 \text { Apr. } 2018 \\
\text { Accepted: } 14 \text { Oct. } 2018 \\
\text { Published: } 04 \text { Apr. } 2019\end{array}$} \\
\hline \multicolumn{2}{|c|}{$\begin{array}{l}\text { How to cite this article: } \\
\text { Mogajane, V.S., Du Plessis, E. } \\
\text { \& Slabbert, E., 2019, } \\
\text { 'Assessing the importance of } \\
\text { spectators to soccer clubs in } \\
\text { South Africa: A management } \\
\text { perspective', Acta Commercii } \\
\text { 19(1), a633. https://doi.org/ } \\
\text { 10.4102/ac.v19i1.633 }\end{array}$} \\
\hline \multicolumn{2}{|c|}{$\begin{array}{l}\text { Copyright: } \\
\text { (c) 2019. The Authors } \\
\text { Licensee: AOSIS. This } \\
\text { is licensed under the } \\
\text { Creative Commons } \\
\text { Attribution License. }\end{array}$} \\
\hline \multicolumn{2}{|l|}{ Read online: } \\
\hline 口ipin: & $\begin{array}{l}\text { Scan this QR } \\
\text { code with your } \\
\text { smart phone or } \\
\text { mobile device } \\
\text { to read online. }\end{array}$ \\
\hline
\end{tabular}

Orientation: This study investigates and analyses the perceptions of soccer club managers based on spectators' loyalty factors, values and challenges concerning soccer clubs in South Africa.

Research purpose: These results could assist managers of soccer clubs to be able to manage these aspects in order to sustain a competitive advantage.

Motivation for the study: This study could contribute to deeper insight into the role of spectators' loyalty, value and how it could contribute to the development of soccer partnerships in South Africa.

Research design, approach and method: In the case of this study, qualitative research was done to obtain relevant information from the senior management of the nine clubs with regard to the aspects of loyalty, the role of spectators within the clubs and the challenges faced by club managers to gain loyal spectators. During face-to-face interviews, the senior management were assured that their answers are confidential and would be used for the purpose of this study as a means of ensuring trustworthiness and qualitativeness. Selecting these people was based on their relevance for the study and their status in the senior management. Each club session interview took one and a half hours at a central location convenient for respondents. The same researcher was present during each of the club's meetings to keep data accurate and consistent. Notes were taken and all sessions were recorded. Respondents in the interview were informed about the aims and procedures of the study.

Main findings: The value of spectators to soccer clubs in South Africa was identified to be commercial value, partnerships value, marketing value and spiritual shareholders value. Marketers need to be aware of their spectators' needs in order to build the relationship and should focus on commitment, customer satisfaction and customer retention as well as trust and brand identification aspects when developing marketing strategies.

Practical/managerial implications: The challenges faced by managers to sustain loyalty to their clubs were identified as absence of heroes, economic climate, safety and security, marketing and public relations. Managers of clubs need to develop their clubs to surpass their current levels of loyal membership and supporters and establish the brand identity of their clubs to increase the satisfaction of their current spectators and to earn more club money for the players.

Contribution/value-add: As stated above, this study focused on assessing the importance of spectators with regard to soccer clubs in South Africa from a management perspective, which could be utilised to gain competitive advantage.

Keywords: challenges; loyalty; soccer; South Africa; spectators; sport; value.

\section{Introduction and background}

In recent years, the behaviour of sport spectators has received increasing attention in academic literature. A better understanding of how and why sport spectators go to stadiums, travel great distances to support their sport clubs and buy merchandise is of great interest to sport marketers (Biscaia 2016:3; Xu 2015:12). Soccer, in particular, is perhaps one of the greatest phenomena in terms of its attraction for hundreds of thousands of occasional spectators of every age and gender, who come together in soccer stadiums around the globe every week to watch the games (Biscaia 2016:3). Understanding sport consumer loyalty is arguably one of the most important concerns in sport marketing and customer-relationship management (Bodet \& Bernache-Assollant 2011:781; Wilkins 2009:27). Kim, Trail and Ko (2011:576) found that a 'good relationship with sport consumers by sport clubs is a critical factor for successful sport business' because it is much cheaper to serve loyal customers and easier to maintain their support (Handley 2012:22). 
Sport clubs are no exception and need to retain spectators; they have been losing these drastically because the market place has become very competitive (Douvis 2014:47; Mullin, Hardy \& Sutton 2007:174; Samra \& Wos 2014:263). Understanding what makes spectators decide to return to the game is important for clubs to be able to formulate relevant effective marketing strategies (Samra \& Wos 2014:263; Shobian 2012:1). Spectators play a significant role in helping sport clubs to generate revenue (Hall, O'Mahony \& Viecell 2009:2). From understanding how the managements of these sport clubs recruit spectators to attend games, sustaining the existence of their spectator base and their perception of spectators' loyalty, the questions that arise are: What is the value of spectators with regard to the soccer club, how do managers foster these spectators and what are the challenges faced by managers inhibiting spectator loyalty to soccer clubs? These results could assist managers of soccer clubs to be able to run their soccer clubs in a more effective and efficient manner in order to sustain a competitive advantage.

\section{Literature review}

Sport industry is a world-reaching business with over US\$620 billion spent annually (Kearney 2011). The sport spending is growing faster than the gross domestic product (GDP), and $43 \%$ of sport market is dominated by soccer, with the least share of 3\% belonging to golf (Kearney 2011). According to Bal, Quester and Plewa (2010:40), the future sport sponsorship in developing countries is growing. South African sponsorship market is estimated to be R7bn (Sport Industry Group South Africa 2012). In South Africa, $70 \%$ corporate spending in sports is on sponsorship (Klayman 2008; Van Heerden \& Du Plessis 2004:71). Key indicators of this trend are investments, for instance made by Amalgamated Banks of South Africa (ABSA), the country's largest retail bank, that invested more than R500 million over 5 years to secure the title rights as main sponsor to the ABSA Premier Soccer League (PSL), as well as the broadcaster SuperSport, which invests significant amounts annually (up to R1.6bn) to secure international sports broadcasting rights for the ABSA PSL games (KickOff 2011).

Soccer as a niche market is described as one of the most popular sports globally (Koo 2009:1; Richelieu, Lopez \& Desbordes 2008:32; Stolt 2010:4). It is the preferred sport with regard to media attention and audience reception (Horne \& Manzenreiter 2002:195; Stolt 2010:4). This is particularly evident in Europe where every year millions of passionate spectators invest time, energy and money in supporting their favourite clubs (Schomburg 2015:24). In South Africa too, soccer is arguably the most popular sport, recreationally and economically, as regards attracting spectators (Dubihlela, Dhurup \& Surujlal 2009:155; Anon 2018).

In most of the European countries, soccer is largely ahead of the other sports, when it comes to attendance, news generated in sport magazines, sport journals or generalist journals. The finances connected to this sport in clubs such as Manchester United, which realised $246.4 \mathrm{~m}$ income in 2004-2005, or Real
Madrid that realised $€ 275.7 \mathrm{~m}$ income in the same season have elevated these clubs to the status of companies, resulting in them becoming more than just soccer clubs (Mays 2012:2). In South Africa, large clubs such as Orlando Pirates and Kaizer Chiefs from the ABSA PSL have managed to secure a deal for broadcasting rights over 3 years for R110m (Solberg 2008:2), making them competitive with European clubs. Recently, ABSA PSL sponsorship income had grown from R119.9m in 2007 to R239.9m in 2011 (PSL Financial Report 2011:57). Further contributions to market and promote ABSA PSL soccer matches from 2014 to 2017 come from South African Broadcasting Corporation (SABC) with the amount of R1376bn (www.thesouthafrican.com). Traditionally, broadcasters got into long-term deals to cover sporting events for a number of years. Today, the demand for owning rights to showcase sporting events has grown so much that these deals have become seasonal. It makes it easier for rights owners to dictate prices and move to the highest bidder at any given time.

Consequently, the soccer industry is now an international business; international professional competitions are established, players are transferred all over the world and the European Championship finals and Fédération Internationale de Football Association (FIFA) World Cup finals are top media events with global television coverage (Fallahi, Asad \& Khabiri 2011:159). The increased globalisation of sport is of great significance to African soccer in general, because this phenomenon has made it easier to buy, scout for and invest in human capital (Solberg 2008:2). Although the current, very challenging economic times are problematic, there is a continued revenue growth in European soccer, illustrating the ongoing loyalty of spectators and the constant appeal of this sport to sponsors and broadcasters (Garcia 2008:3). In South Africa, the commercialisation of soccer has resulted in an increase in revenue with other sponsors wanting to invest their capital in the ABSA PSL.

While the finances of professional soccer clubs have increased massively in terms of revenue (Koo 2009:1; Schomburg 2015:1), the spectators, among others, have experienced important changes in the cultural organisation of the sport (Giulianotti \& Robertson 2004:545). A change of culture frequently occurs along with certain traditions being lost by clubs that have been commercialised (Krabbenbos 2013:2). Furthermore, Krabbenbos (2013:2) explains the interesting situation in soccer where the minority of clubs are owned by their supporters. In these so-called membership clubs, the ownership is spread between a large number of spectators. Consequently, the spectators at these clubs have an important influence on how the club is commercialised. Literature supports this: studies by Immamovic (2010:173) and Bodet and Bernache-Assolant (2011:783) describe the value of spectators from these sport clubs as being essential and contributing to the development of the sport.

Sport spectating is one of the most popular leisure activities with the spectators representing the largest proportion of the sport industry (Kim 2008:13). According to Chao (2010:5), 
these spectators are a group of consumers who support the popularity of a team. They are, in many instances, fanatical about the performance and success of their team (Gerber \& Terblanche 2012:75). Wilkins (2012:73) and Gerber and Terblanche (2012:75) mentioned factors such as eustress, selfesteem, escape, entertainment, aesthetics, group affiliation and family needs as components of the motivation that leads to attendance at sports events. Understanding the factors that influence spectator attendance is fundamental to understanding decisions about sport consumption (Gerber \& Terblanche 2012:75; Kruger, Saayman \& Ellis 2010:91-92). Spectator attendance at sport events represents a significant revenue stream for sports venues and sports associations, with subsequent benefits for cities or regions, and is estimated to be worth millions (Hall et al. 2009:2). This is not surprising because sports marketing revenue comes from ticket sales, while sponsorship revenue depends on how popular and well attended the given sport or team game is (Kim \& Trail 2010:190).

This holds true for South Africa, where popular soccer teams such as Orlando Pirates, Kaizer Chiefs and Sundowns have a large following and spectator base (Feinberg 2010). The major difference between these clubs may be in their brand value (Koo 2009:2). One of the main disadvantages of increasing commercialism is the alienation of soccer spectators. As a result of these changes, supporters can often no longer identify with their soccer club and a consequent lack of satisfaction among them starts to develop (Krabbenbos 2013:2). Kennedy and Kennedy (2012:327) write that spectators have been very resistant to the commercialisation of soccer. Because of the advent and increasing dominance of commercialisation within the soccer industry, spectators have seen their soccer clubs transform from traditional community clubs into corporate business organisations. As a result, they, the spectators, as mentioned above, have difficulty in identifying with their club and become dissatisfied. Thus, it can be stated that while studies reveal dissatisfaction with commercialisation (Crompton 2014:420), they also indicate that loyalty programmes, which involve benefits and incentives, could foster loyalty to the clubs.

Studies on loyalty mentioned that satisfaction with club games has been referred to as an antecedent of the spectators, behavioural intentions and their emotions experienced during the matches, service quality, team brand associations, commitment, brand identification, perceived value, customer relationship, trust, customer retention, waiting time and dependability are loyalty consumption-related aspects often mentioned as having a direct or indirect role (i.e. via satisfaction) in increasing spectators' behavioural intentions (Abeza, O'Reilly \& Reid 2013:120; Baker \& Jones 2011:52; Biscaia et al. 2013:14-25, 20-32; Choi et al. 2009:268; Dagger, David \& Ng 2011:273; Haghkhah et al. 2013:159; Kotler \& Armstrong 2014:27; Kuenzel \& Halliday 2010:167; Lager 2008:30-330; Martin et al. 2008,22:224-236; Stavros, Pope \& Winzar 2008:135; Toedt 2014:229; Van Vuuren, RobertsLombard \& Van Tonder 2012:96; Van Vuuren et al. 2012:96;
Wu, Tsai \& Hung 2012:180; Yoshida \& James 2010:338; Zhao, Hou \& Gilbert 2014:296).

Research (Gerber \& Terblanche 2012:75; Howard \& Crompton 2005:32; Immamovic 2010:189-246; Kim \& Trail 2010:192; Kruger et al. 2010:91-92; Yoshida \& James 2010:338) has identified several factors such as prizes, inclement and deterrent weather before and during the event, lack of resources and access, time conflict between the professional tournament and everyday life activities, inconvenience, lengthy distance to travel to the event, poor player performance, seating and difficulty in finding parking as constraints and challenges faced by managers that impact on spectator attendance at the games.

Research by Douvis (2014:42) indicated that a game's attractiveness and audience preference are positively related to attendance of a game. Furthermore, promotion and income have consistently been found to be positively related to game attendance, while ticket price, substitute forms of entertainment, the television effect as well as competition from other sport events have been found to be negatively related to game attendance (Douvis 2014:44). In order to sustain the growth of soccer clubs, it is vital to acknowledge the importance of spectators and understand the factors that foster their loyalty to specific soccer clubs in order to manage this process and overcome the challenges.

\section{Main problems to be investigated}

For any sporting event to be successful and profitable, it not only needs sport respondents but also spectator attendance (Drapper \& Coalter 2016:49; Huang, Lee \& Hou 2009:80, Stander \& Van Zyl 2016:2; Tichaawa \& Harila 2016:797-798). Developing and maintaining a long-term relationship with spectators, independently from team performance, is important for their loyalty to and management of the clubs. South Africa has a unique situation pertaining to loyalty to soccer clubs where aspects such as the economic environment of spectators, the high unemployment rate in the country, transport issues and various other aspects all play a role. Sport managers need to understand what motivates spectators to attend sporting events and what hinders them from attending the games (Drapper \& Coalter 2016; Huang et al. 2009:80; Stander \& Van Zyl 2016:2; Tichaawa \& Harila 2016:797-798) in order to establish a successful long-term relationship. No information or guidelines in the South African context give guidance to the managers of these clubs, and therefore the question remains: What are the value of spectators to soccer clubs, the loyalty factors contributing to this loyalty and the challenges faced by managers in the quest to gain loyal spectators?

\section{Methodology}

To achieve the objectives of the study, a descriptive paradigm was used, employing a qualitative research design. This study was carried out following a multiple case study approach. In the case of this study, qualitative research was conducted 
to obtain relevant information from the senior management of the nine clubs with regard to the aspects of loyalty, the role of spectators within the clubs and the challenges faced by club managers to gain loyal spectators. During face-to-face interviews which lasted for one and a half hours, the senior management were assured that the answers they provide are confidential and to be used for the purpose of this study as a means of ensuring trustworthiness and qualitativeness. Selecting these people was based on their relevance for the study and their status in the senior management. Each club session interview took place at a central location convenient for respondents. The same researcher was present during each of the club's meetings to keep and record data accurately and consistently. Notes were taken and all sessions were recorded. Respondents in the interview were informed about the aims and procedures of the study. Limitations of the study are that out of nine respondents only one was female and this cannot be regarded as a true representative of females. The nine clubs do not have the same financial injection and strength invested by the sponsors. An important limitation of this study is that even though the results may be representative of club managers with regard to spectators, generalisation of the findings in the wider context is limited. The results of the study also pertain only to soccer spectators, and therefore one cannot infer the findings to all sports spectators

\section{Case study}

The ABSA PSL is a national sports association responsible for administering the two professional soccer leagues in South Africa - the South African Premier Division and National First Division. The ABSA PSL was created following an agreement between the National Soccer League and the remnants of the National Premier Soccer League (NPSL). The company acts as a governing body and competition organiser. The ABSA PSL is affiliated to the South African Football Association (SAFA) but SAFA does not govern the ABSA PSL competitions. The National First Division (NFD) is the second-highest league of South African club soccer. Teams that are relegated from the ABSA PSL's organised divisions compete in the SAFA Second Division.

\section{Research design and sample}

The identification of the value of spectators, the aspects contributing towards loyalty as well as the challenges faced by the clubs could offer some insight into their management. In order to accomplish this, a qualitative research approach was followed by interviewing nine club managers. The managements of these clubs were selected on the basis of their experience in this environment and their work and understanding of marketing. The ABSA PSL consists of 16 clubs. Nine were selected because of their popularity and average performance in the ABSA PSL.

A qualitative approach (rather than a quantitative methodology) was chosen because it would provide richer data that are more appropriate for this research (Rahman 2016:102). Each club session interview took place at a central location convenient for respondents. Each interview was scheduled in advance, with confirmed dates. Collected data were transcribed into text and presented in narrative form, after which this was analysed by using Creswell's six steps in data analysis and interpretation.

\section{Guidelines for the interviews}

Structured interviews are usually adopted in multiple case studies to ensure structure and guarantee that the questions are detailed and developed in advance, for example as in a research survey (Nieuwenhuis 2008:47). The interview schedule comprised two parts. The first was intended to collect the demographic information of these managers, considering their gender, age range and duration in their current position in the clubs. The second part consisted of questions that were structured to gather in-depth information on three main aspects: the value of loyal spectators, current management practices in fostering loyalty and challenges inhibiting loyalty to soccer clubs. The questions were formulated based on the research of Agbor (2011) and Chao (2010) as found in the literature. The instrument was pretested for usability and clarity in a pilot study carried out at smaller clubs in the North West province of South Africa.

\section{Data analysis}

Based on the responses of the respondents, follow-up questions were formulated as appropriate. Interviews were audiotaped, transcribed and, subsequently, further analysed by the authors. The researchers employed the following six steps as suggested by Creswell (2009:175-177):

- Organise and prepare the data. This included organising the data as well as the transcriptions of the recorded interviews and preparing them for analysis. Research was also conducted by employing content analysis utilising the search results of numerous scholarly journals that have conducted research on spectators of sport clubs, in order to obtain background regarding the management of such clubs.

- Read through all the data. During this step, the data were read through several times in order to obtain a general sense of the information.

- Begin a detailed analysis with a coding process. The data were coded in order to identify the important aspects. Thereafter, a recode process was followed by the authors in order to ensure trustworthiness. The results were then compared with one another in order to gain an overall perspective.

- Use the coding process to generate a description of the setting or people as well as categories or themes for analysis. The various codes were then divided into categories, after which themes were allocated to each category. The allocated themes appear as the major findings in the results and were used to create headings in the findings section of this study.

- Advance how the description and themes will be represented in the qualitative narrative. A discussion follows, mentioning 
the chronology of the importance of the themes identified. This step conveys descriptive information about each given theme and the information identified by each respondent.

- A final step in data analysis involves interpreting or making meaning of the data. Lastly, personal interpretation and understanding were formulated with regard to the results gained from this research.

Trustworthiness is an indication of methodological soundness and adequacy (Holloway \& Wheeler 2010). For this research, trustworthiness was illustrated by means of coding and recoding the data and testing it against results found in literature.

\section{Ethical considerations}

Issues of confidentiality were taken into consideration, and the respondents were assured that data would be kept confidential and that their names would not be mentioned. Ethical approval was obtained (ethical clearance number: EMS 2016/11/04/-02/28) through the ethical process of the university.

\section{Results and discussions}

The results based on the survey that was conducted follow.

\section{The demographics characteristics of the club managers}

The first part of the questionnaire was developed to capture the information regarding the demographic details of the club managers and included the following characteristics as presented in Table 1.

From Table 1, it is clear that the ABSA PSL clubs appoint more men than women to be their marketing managers. With regard to the age difference, there are more marketing managers (6) in the category 30-40 years compared to the categories 20-30 years (1), 40-50 years (1) and 50-60 years (1). What is interesting to note from Table 1 is that every marketing manager has attained at least a post-matric qualification, which puts them in a stronger position, even though some of them do not possess relevant marketing qualifications.

\section{Results of the management aspects}

The second part of the questionnaire focused on the main objective of this study, that is, to assess the importance of spectators based on the perceptions of the managers as regards the value of the spectators, the current management practices in fostering loyalty as well as the challenges faced by managers of soccer clubs. Managers were asked to indicate their perceptions of these issues. Referring to the fourth step of Creswell's (2009) guidelines, the various factors that were mentioned by the managers were categorised and allocated to themes.

\section{Value of spectators}

In conducting the interviews with the nine managers of the soccer clubs, four themes were identified with regard to the value of spectators: commercial value, partnership value, marketing value and spiritual shareholders value. These themes were based on previous research that gives guidance in terms of spectator values. Value themes were also developed based on the primary context of the elements as part of the specific group.

Respondents were asked if their teams value the importance of having spectators; the following supporting statements were made by the respondents (presented as 1, 2, 3, 4, 5, 6, $7,8$ and 9$)$.

From Table 2, it is clear that all the respondents regarded spectators as valuable partners in the success and the growth of their teams (Douvis 2014:48; Misener \& Doherty 2012:243).

Theme 1: Commercial value: Within the theme of commercial value, constructs such as tickets, merchandise and club membership were mentioned (respondents 1, 2, 3, 4 and 7). Respondents 1 and 4 highlighted the importance of commercial value in maintaining a successful sports club by stating that 'it will make a vast difference to budgets and it would help the management to run the club even better'. This could be considered as the second most important theme

TABLE 1: The demographic characteristics of the club managers.

\begin{tabular}{lllll}
\hline Demographics & Gender & Age & Occupation & Education \\
\hline Respondent 1 & Male & 29 & Media and Marketing Manager & Diploma in Journalism and Media \\
Respondent 2 & Male & 34 & Marketing Manager & BCom in Information Sciences \\
Respondent 3 & Male & 43 & Marketing and Public Relations Manager & BEd Hons in Education \\
$\begin{array}{l}\text { Respondent 4 } \\
\text { Respondent 5 }\end{array}$ & Female & 44 & Marketing Director and Sales & Diploma in Communication and Marketing \\
Respondent 6 & Male & 58 & Marketing Manager & Master in Business Administration \\
Respondent 7 & Male & 45 & Public Relations Officer & B Juris \\
& & 41 & Chairman & Higher Diploma in Company Law \\
& & & & Higher Diploma in Taxation Law \\
Postgraduate diploma in Cyber Law & Certificate in Management & FIFA/Sport Management \\
Respondent 8 & & & General Manager & Diploma in Marketing \\
Diploma in Sport Management & Marketing Manager & \\
\hline
\end{tabular}

LLB, Bachelor of Law. 
TABLE 2: Responses of respondents towards the value of spectators.

\begin{tabular}{lll}
\hline Respondents & Factors contributing to theme & Identified theme \\
\hline $1,2,3,4,7$ & $\begin{array}{l}\text { Tickets } \\
\text { Merchandise } \\
\text { Club membership }\end{array}$ & Commercial value \\
\hline 6 & $\begin{array}{l}\text { Media } \\
\text { Sponsors } \\
\text { Companies }\end{array}$ & Partnership value \\
& $\begin{array}{l}\text { Word of mouth } \\
\text { Ambassadors } \\
\text { Advertisement }\end{array}$ & Marketing value \\
& $\begin{array}{l}\text { Connection/attachment to team } \\
\text { Quality of soccer } \\
\text { Performance of players } \\
\text { Community growth } \\
\text { Generations immemorial/emotional position } \\
\text { Motivate success }\end{array}$ & $\begin{array}{l}\text { Spiritual } \\
\text { shareholder value }\end{array}$ \\
& & \\
\hline
\end{tabular}

indicated by the respondents, based on their reaction to the importance of spectators buying tickets, merchandise and being part of the club.

This is supported in studies undertaken by Mullin et al. (2007:22) and by Xu (2015:14) which suggest that one of the main goals of sport is to build and market an event in such an appealing way that sport or club marketers will convince their target consumers to buy into the event, either live (e.g. by attending the match) or via the media (e.g. watching the match on television), both of which indicate the commercial value of the spectators.

Theme 2: Partnership value: Shank (2005:12), Misener and Doherty (2012:245) and Xu (2015:1) further emphasised that to reap the benefits of a loyal consumer base, the interests of the three types of consumers identified as spectators, respondents and corporate business are critical in the growth and the development of the team, which could result in sponsorships built on these partnerships.

It could be argued that theme 2, partnerships, could be included with theme 1 that focuses on commercial value for the club. However, these partnerships do not only contribute financially to the club but also motivate an emotional connection (respondents 4 and 5). Sponsors invest in soccer clubs that provide greater mileage in return for an investment (Misener \& Doherty 2012:243; Shank 2005:12; Xu 2015:3). Companies today associate themselves with clubs which have a huge spectator base, and which give them the opportunity to sell their products. The products might be merchandise and information which can be derived from newspapers or television. The soccer game which spectators attend can also be referred to as a product because they come to the game to 'consume' it (figuratively speaking) or enjoy themselves. The game of soccer involves many aspects such as owners of the clubs who will invest in the team in order to be successful. In the same vein, agents will use the opportunity to manage players' contracts so that they themselves (the agents) are in turn able to benefit (Misener \& Doherty 2012:243; Shank 2005:12; Xu 2015:3).

Theme 3: Marketing value: As part of the literature investigating respondents, Xu (2015:3), Fullerton (2010:36) and O'Reilly, Graham and Rennie (2013:1-3) consider that sport marketing consists of three subsystems: the media, the sponsors and the spectators. The relationship between these three subsystems is symbiotic as they collaborate in order to attract additional spectators to a sporting event (Fullerton 2010:36; O'Reilly et al. 2013:1-3; Xu 2015:3). Respondents 6, 2,3 and 7 confirm this sentiment by stating that spectators play an ambassadorial role, they are foot soldiers, they deal by word of mouth and they effectively advertise for the club. The interviewee stressed that these spectators are referred to as the 'each one teach one' kind of people.

For example, the media supply the amount of coverage needed, as determined by the interest level of the spectators, as well as the level of credibility that the sponsors can afford. Furthermore, sponsors provide financial support to the sport organisation, dependent upon the level of spectator interest as well as the available media partnership. Lastly, the level of spectator support for a sport organisation may influence the number of sponsors attracted to the club (Xu 2015:3), which therefore supports the first and second themes identified.

Theme 4: Spiritual shareholder value: It is clear from the interviews that the value added by spectators to a team or sport club is very important. All the respondents accept this; respondent 3 indicated it as the most important role of spectators in terms of a soccer sport club in South Africa. They highlighted factors such as connection or attachment to the team (respondents 4 and 5), influencing the quality and performance of the players of the soccer being played (Respondents 1, 2, 8 and 9), motivation to success for both management and players (Respondent 2), emotional connection that add to the brand (Respondent 4), loyal older people from generations immemorial adding value by attracting family and friends (Respondent 6), spiritual stakeholders with great influence (Respondent 7) and soccer spectators could influence the community to grow (Respondent 8).

These factors were also indicated by Yoshida and James (2010:338) as well as Martínez, Ko and Martínez (2010:502) who stated that the quality of the game is an important aspect of attracting spectators to the games.

\section{Aspects of spectator loyalty}

Respondents were asked whether their teams promote aspects of loyalty. These aspects differ from the traditional loyalty aspects mentioned in literature, such as commitment (Ruyruen \& Miller 2007:21); customer satisfaction (RobertsLombard 2009:413); customer retention (Khan 2012:107); and trust, building pride and spiritual connection (Costabile 2000:77-78; Gommans, Krishnan \& Scheffold 2001:50).

It was clear to the researcher that the respondents did not perceive loyalty aspects in the same way as that indicated in the literature; in addition, their responses explained aspects that foster spectators' loyalty towards the soccer clubs and teams.

One could divide the factors mentioned by the respondents into sub-themes such as incentives, benefits, discounts and 
additional services, but in essence these boil down to tangible benefits in the form of discount tickets (Respondents 1, 2, 3, 4, 5, 6 and 7); transport to the match (Respondents 3, 5 and 7); accommodation discounts near the stadium as an incentive (Respondent 3); clothing discounts (Respondents 3 and 7); other incentives such as funeral plans, legal policies and airtime as a member of the club (Respondents 4,5 and 9).

The results demonstrate that to a large extent, all clubs believe that the spectators do benefit from their teams; in consequence, information is shared with spectators and the clubs are able to market their teams through playing good soccer (respondents 1, 2, $3,4,5,6,7,8$ and 9). According to the literature, Yoshida and James (2010:338) mentioned that satisfaction is found by creating an exciting game and atmosphere which positively influences spectators to return for future events. Thus, sport spectators become more concerned about pleasure, enjoyment and their experience of a positive feeling about the game. This research has found that the South African managers focus on influencing the atmosphere and the loyalty of the spectators and of the match by providing benefits, incentives and additional services to create satisfaction and a memorable experience. This supports the research by Martínez et al. (2010:502), which states that professional sports organisations should offer high-quality sports spectating products or services to attract more sport spectators to the games.

These results could also add to the sentiments expressed by Couvelaere and Richelieu (2005:24) and Yoshida and James (2010:338) that indicated physical facilities and other elements (such as in this study) could enhance the experience and help create a feeling of belonging to the team, thereby contributing to the development of a sports team brand.

\section{The challenges facing Amalgamated Banks of South Africa Premier Soccer League clubs}

In conducting the interviews with the nine managers of the soccer clubs, five themes were identified with regard to the challenges managers faced concerning loyalty, which were grouped as absence of heroes, economic climate, safety and security, marketing and public relations.

The following challenges regarding loyalty were mentioned by the respondents:

Challenge 1: Absence of heroes: According to the respondents ( 5 and 7 ), the current players do not play entertaining soccer; as a result, they do not attract spectators to the games. A lack of heroes or iconic players is a huge concern for managers of the soccer clubs. The indications from the respondents (4 and 5) are that there are no longer iconic players loved by spectators who attract spectators to the clubs because of them. Respondents (2, 3, 4, 5 and 6) mentioned that spectators will attend a game that is exciting and produces winning results. Wann et al. (2001:2) assert that the value of sport spectating lies in the fact that spectators are interested in sport and as a result spend a considerable amount of money to actively follow a sport, team and/or athlete. Sport spectators who perceive a high-quality relationship with a team or athlete will invest more time and money in the team by attending games and purchasing licensed products (Williams \& Chinn 2010:423). Individual players are often major drawcards to lure spectators. For instance, Real Madrid paid Manchester United $€ 94 \mathrm{~m}$ for the purchase of Cristiano Ronaldo (Hughes 2009:1).

Challenge 2: Economic climate: Most spectators make sacrifices so as to be able to attend and support their clubs even though they are unemployed. According to the respondents (3, 8 and 9), many of the spectators are unable to renew their club memberships when these expire because of the lack of money. According to the literature, in South Africa, the enormous economic challenges resulting from unemployment and high levels of poverty (Segalo 2011:229) impact on the extent to which society supports sport. Although South Africans are challenged by the said socio-economic factors, the popularity of soccer is visible in the township streets where it is a common boys' game (Alegi \& Bolsmann 2013:8), while people nevertheless try to attend the soccer games despite these challenges.

Challenge 3: Safety and security: It was also mentioned by respondents 1, 2, 4 and 5 that the games played at night posed risks to the spectators' lives. Safety and security has been identified as one of the five global forces that will drive the sports tourism industry in the new millennium. George (2003:575) and Du Plessis, Saayman and Van der Merwe (2017:1) found that if individuals feel a particular destination is either risky in terms of safety or security, they are most likely to develop a negative impression about the place, resulting in avoiding it. Attendance of games at night for spectators therefore becomes a huge risk.

Challenge 4: Marketing: All of the respondents (1, 2, 3, 4, 5, 6, 7,8 and 9) indicated that marketing (including television and technology) is not properly addressed by their clubs; as a result, this impacts on attendance and the recruitment of spectators. The respondents also stated that sponsors find it difficult to sponsor clubs as there are competing needs. From a marketing management perspective, it is important that spectators are taken into consideration because they are able to profit significantly (Douvis 2014:50-51; Johnston 2004:21). A key question facing sport marketing management is how to develop, maintain and grow loyalty, not just among successful sporting clubs but also among teams with inferior or poor results (Douvis 2014:52; Johnston 2004:21). The main goal of the marketing function of a club should be to develop and maintain relationships with spectators, as well as to boost the popularity of the game (Handley 2012:22; Samra \& Wos 2014:263). Spectators should be treated as club stakeholders: their needs to belong to a club, to express their views and opinions about a club as well as to be acknowledged as spectators of a club's games should all be satisfied.

Challenge 5: Public relations: Most of the respondents (2, 3, $4,5,6,7,8$ and 9) mentioned that although they provide corporate social investment (CSI) projects to communities, 
loyalty programmes are not necessarily implemented by the clubs, which they must introduce to spectators. While sport clubs are not as advanced with regard to the loyalty learning curve as some sectors, such as airlines with their Frequent Flyer Points or supermarkets and fuel companies and their loyalty programmes, there has been significant progress in this area (Johnston 2004:21). Major clubs in the United States, Britain as well as South Africa (Bester 2010:186) now run loyalty programmes (Lundmark 2017:5). Good customer loyalty programmes not only improve consumer acceptance that is reflected in increased sales but also encourage participation through increased interaction between the business and customer (Ou et al. 2011:195-196). It is therefore critical that all soccer clubs in South Africa implement loyalty programmes to attract a significant number of spectators to support their teams.

\section{Findings and recommendations}

The first finding highlights the four identified themes of the value of spectators to soccer clubs in South Africa: commercial value, partnership value, marketing value and spiritual shareholder value. Although similar themes and factors have been identified in the literature, these themes and factors differ from those of other soccer clubs in the world, indicating the uniqueness of South Africa as a destination and also the unique spectator base. This finding also demonstrates that spectators are regarded as valuable partners ( $X u$ 2015:5) in the success and the growth of their club. Therefore, managers should determine the value of spectators to their clubs and capitalise on this in order to manage their club successfully. The former should be able to provide goods and services to attract spectators in order to grow and sustain the clubs. They should use the knowledge regarding spectators in order to build a brand that instils trust, identification, value, commitment, quality and satisfaction. This will aid in generating additional revenues through the sale of a variety of goods and services.

The second finding highlights the different views that the managers of soccer clubs express in terms of loyalty aspects. South African club managers foster loyalty by providing benefits, incentives, discounts and additional services to spectators. This is unique to the South African context which emphasises the importance of the needs of spectators in the creation of loyalty. Management indicated that different aspects come into play in South Africa when cultivating the loyalty of spectators. For sustaining or even enhancing loyalty, marketers need to be market focused and be aware of their customers' preferences in order to build such a relationship as that of lifetime partners and should attempt to understand their changing wants, desires and values.

The third finding highlights the challenges faced by managers in sustaining loyalty to their clubs, which in essence threaten the sustainability of the club. Themes that were identified were absence of heroes, economic climate, safety and security, marketing and public relations. It is clear that the quality of the game, players, facilities and management, value for money and the overall experience of the spectators are of utmost importance to gain a competitive advantage. It is obvious that the first and main objective of soccer clubs is to make money, but it could be assumed from the results that for the South African spectator the objective is much more about the game and the heroes. This could be because their frame of reference to the sport differs from international clubs. Therefore, managers of clubs should invest in identifying the constraints of potential spectators and developing strategies to reduce those constraints and challenges in order to create loyal spectators, which in the end will provide the income for the clubs.

The last finding highlights the importance of soccer in South Africa but it was also clear that it should be managed differently because of the spectators that are regarded as valuable partners in the success and the growth of their club. Furthermore, sponsors invest in soccer clubs that provide mileage in return as an investment. It was indicated that airtime was important to spectators, and companies such as Vodacom and Mobile Telephone Network (MTN) could capitalise on this information by providing incentives to spectators at a particular game. Therefore, managers of clubs need to go beyond their status as mere sports teams and establish themselves as brands in their own right.

\section{Conclusions}

This study is the first of its kind where a critical analysis was performed with regard to the importance of spectators, in terms of their value, loyalty and challenges faced by managers, applied to the sport context in South Africa. It is clear that the South African soccer scenario is unique in comparison with global soccer clubs. It is perceived as an important recreational outlet for the majority of the population of South Africa. In order to sustain this and foster the sport of soccer, it is important for managers of soccer clubs to adapt to the daily changes of spectators needs, views and perceptions towards the sport.

\section{Acknowledgements Competing interests}

The authors declare that they have no financial or personal relationships that may have inappropriately influenced them in writing this article.

\section{Authors' contributions}

This research formed part of the $\mathrm{PhD}$ study conducted by V.S.M., which was supervised by E.d.P., and E.S. acted as co-supervisor.

\section{Funding}

Funding for this research was provided through a study grant from the National Research Foundation. 


\section{References}

Abeza, G., O'Reilly, N. \& Reid, I., 2013, 'Relationship marketing and social media in sport', International Journal of Sport Communication 6, 120-142. https://doi.org/ 10.1123/ijsc.6.2.120

Agbor, J.M., 2011, 'The relationship between customer satisfaction and service quality: A study of the service sections in Umeå', MA Dissertation, School of Business, Umeå University.

Alegi, P. \& Bolsmann, C., 2013, South Africa and the global game. Football, Apartheid and beyond, Routledge, Taylor and Francis Group, Abingdon, Oxon.

Anon, 2018, South African blog awards, viewed 02 March 2018, from http:// thesportseagle.co.za/5-biggest-sports-south-africa/

Baker, T. \& Jones, S.A., 2011, 'The inevitable queue: Exploring the impact of wait time at sporting events', International Journal of Sports Marketing and Sponsorship 1(10), 49-59. https://doi.org/10.1108/IJSMS-13-01-2011-B005

Bal, C., Quester, P. \& Plewa, C., 2010, 'Emotions and sponsorship: A key to global effectiveness? A comparative study of Australia and France', Asia Pacific Journal of Marketing and Logistics 22(1), 40-54. https://doi.org/10.1108/13555851011013146

Bester, P., 2010, 'An environment analysis of cycling in South Africa', MA Dissertation, Pretoria, University of South Africa.

Biscaia, R., 2016, 'Revisiting the role of football spectators' behavioural intentions and its antecedents', The Open Sports Sciences Journal 9(1), 3-12. https://doi. org/10.2174/1875399X01609010003

Biscaia, R., Correia, A., Rosado, A., Ross, S. \& Maroco, J., 2013, 'Sport sponsorship: The relationship between team loyalty, sponsorship awareness, attitude toward the sponsor, and purchase intentions', Journal of Sport Management 27, 288-302. https://doi.org/10.1123/jsm.27.4.288

Bodet, G. \& Bernache-Assolant, I.B., 2011, 'Consumer loyalty in sport spectatorship services: The relationship with consumer satisfaction and team identification' Journal of Psychology and Marketing 28(8), 781-802. https://doi.org/10.1002/ mar.20412

Chao, T.H., 2010, 'Motivation of sport fans on different channels of sport entertainment', MSc Dissertation, Purdue University, West Lafayette, IN.

Choi, Y.S., Martin, J.J., Park, M. \& Yoh, T., 2009, 'Motivational functions influencing sport spectator involvement at NCAA Division II basketball games', Journal for the Study of Sports and Athletes in Education 3(3), 265-284. https://doi.org/10.1179/ ssa.2009.3.3.265

Costabile, M., 2000, 'A dynamic model of customer loyalty', paper delivered at the16th IMP Conference held in Bath, UK on 7-9th September, viewed 18 July 2012, from http://www.impgroup. org/uploads/papers/43.pdf

Couvelaere, V. \& Richelieu, A., 2005, 'Brand strategy in professional sports: The case of French soccer teams', European Sport Management Quarterly 5(1), 23-46. of French soccer teams', European Sport Mand
https://doi.org/10.1080/16184740500089524

Creswell, J.W., 2009, Research design: Qualitative, quantitative and mixed methods approaches, 3rd edn., Sage, London.

Crompton, J.L., 2014, 'Potential negative outcomes from sponsorship for a sport property', Managing Leisure 19(6), 420-441. https://doi.org/10.1080/13606719. 2014.912050

Dagger, T.S., David, M.E. \& Ng, S., 2011, 'Do relationship benefits and maintenance drive commitment and loyalty?', Journal of Service Marketing 25(4), 273-281. https://doi.org/10.1108/08876041111143104

Douvis, J., 2014, 'What makes fans attend professional sporting events? A review', Advances in Sport Management Research Journal (1), 40-70.

Drapper, C.E. \& Coalter, F., 2016, “'There's just something about this club. It's been my family." An analysis of the experiences of youth in a South African sport-fordevelopment programme', International Review for the Sociology of Sport 51(1) 44-60. https://doi.org/10.1177/1012690213513783

Dubihlela, J., Dhurup, M. \& Surujlal, J., 2009, 'Motivational factors affecting fan decisions to attend Premier Soccer League (PSL) games in South Africa: Sport management', African Journal of Physical Health Education, Recreation and Dance 9(9), 155-171. https://doi.org/10.4314/ajpherd.v15i4.47288

Du Plessis, E., Saayman, M. \& Van der Merwe, P., 2017, 'How has South Africa's competitiveness changed over the last 12 years?', South African Journal of Economic and Management Sciences 20(1), 1-11.

Fallahi, A., Asad, H. \& Khabiri, M., 2011, 'The comparison of the importance of the factors affecting spectators' attendance in football matches in Iranian Professional League within age groups', World Journal of Sport Sciences 4(2),159-165.

Feinberg, N., 2010, Laduma! Soccer in South Africa, viewed 02 July 2010, from http:// www.boell.org.za/web/144-544ht ml

Fullerton, S., 2010, Sports marketing, 2nd edn., McGraw-Hill Education, New York.

Garcia, B., 2008, 'The European Union and the governance of football: A game of levels and agendas', PhD Thesis, Loughborough University, Loughborough.

George, R., 2003, 'Tourist's perceptions of safety and security while visiting Cape Town', Tourism Management 24(5), 575-585. https://doi.org/10.1016/S0261 5177(03)00003-7

Gerber, C. \& Terblanche, N.S., 2012, 'Team performance and sport attendance of South African Super Rugby and Currie Cup rugby fans', South African Journal for Research in Sport, Physical Education and Recreation 34(1), 75-91.

Giulianotti, R. \& Robertson, R., 2004, 'The globalization of football: A study in the glocalization of the serious life', The British Journal of Sociology 55(4), 545-568. https://doi.org/10.1111/j.1468-4446.2004.00037.x
Gommans, M., Krishnan, K.S. \& Scheffold., B., 2001. 'From brand loyalty to e-loyalty: A conceptual framework'. Journal of Economic and Social Research 3(1), 43-58.

Haghkhah, A., Hamid, A.B.B.A., Ebrahimpour, A., Roghanian, P. \& Gheysari, H., 2013, 'Commitment and customer loyalty in business-to-business context', European Journal of Business and Management 5(19), 156-164.

Hall, J., O'Mahony, B. \& Viecell, J., 2009, A model of predictions of attendance at major sporting events, Australian \& New Zealand Marketing Academy (ANZMAC), Melbourne.

Handley, L., 2012, 'Brands must get set for the swift response', Marketing Week, 29 March, p. 22

Holloway, I. \& Wheeler, S., 2010, Qualitative research in nursing and healthcare, 3rd edn., Wiley-Blackwell, Chichester, UK.

Horne, J. \& Manzenreiter, W. (eds.), 2002, 'The World Cup and television football', in J. Horne \& W. Manzenreitereds (eds.), Japan, Korea and the 2002 World Cup pp. 195-212, Routledge, London.

Howard, D.R. \& Crompton, J.L., 2005, Financing sport, (2nd edn.), Fitness Information Technology, Morgan Town, WV.

Huang, C.H., Lee, C.H. \& Hou, C.S., 2009, 'Segmenting motivations for the satisfaction of spectators in 2009', World Games: 2011 International Conference on Innovation, Management and Service, IPEDR, Singapore, 2011, 14, pp. 79-84

Hughes, R., 2009, 'Ronaldo to join Real Madrid for record price', New York Times, viewed 25 October 2012, from http://www.nytimes.com/2009/06/12/sports/ soccer/12iht-RONALDO.html

Immamovic, N., 2010, 'Tennis spectator loyalty when life gets in the way', MA Dissertation, University of Waterloo, Canada.

Johnston, D., 2004, 'Consumer loyalty amongst sport fans: AGF case study', MA Dissertation, Aarhus University, Denmark.

Kearney, A.T., 2011. The Sport Market: Major trends and challenges in an industry full of passion, West Adams Street, Chicago, IL.

Kennedy, P. \& Kennedy, D., 2012, 'Football supporters and the commercialisation of football: Comparative responses across Europe', Soccer \& Society 13(3), 327-340. https://doi.org/10.1080/14660970.2012.655503

Khan, O., 2012, 'Towards understanding customer loyalty: An empirical study on emotional attachment', International Journal of Innovations in Business 1(3), 241-267.

KickOff., 2011, Soweto Derby worth the hype, viewed from http://www.kickoff. com/ news/20469/soweto-derby-worth-the-hype

Kim, Y.K., 2008, 'Relationship framework in sport management: How relationship quality affects sport consumption behaviours', PhD Thesis, University of Florida.

Kim, Y.K. \& Trail, G., 2010, 'Constraints and motivators: A new model to explain sport consumer behaviour', Journal of Sport Management 24 190-210. https://doi. $\mathrm{org} / 10.1123 / \mathrm{jsm} .24 .2 .190$

Kim, Y.K., Trail, G. \& Ko, Y.J., 2011, 'How relationship influences sport consumption behavior? An empirical examination of the relationship quality framework', Journal of Sport Management 25, 576-592. https://doi.org/10.1123/jsm.25.6.576

Klayman, B., 2008, Global sports market to hit \$141 billion in 2012" published in Reuters on 18 June 2008, viewed 20 August 2018, from http://www.reuters.com/ article/2008/06/18/us-pwcstudy-idUSN1738075220080618

Koo, J.J., 2009, 'Brand management strategy for Korean professional football teams: A model for understanding the relationships between team brand identity, fans' identification with football teams and team brand loyalty', PhD Thesis, Brunel University, London.

Kotler, P. \& Armstrong, G., 2014, Principles of marketing, 15th edn., Pearson Education International, Upper Saddle River, NJ.

Krabbenbos, T., 2013, 'Commercialization strategies in football', MA Dissertation, Enschede, University of Twente, Netherlands.

Kruger, M., Saayman, M. \& Ellis, S.M., 2010, 'Does loyalty pay? First time versus repeat visitors at a national festival', South African Business Review 14(1), 79-104.

Kuenzel, S. \& Halliday, S.V., 2010, 'The chain of effect from reputation and brand personality congruence to brand loyalty: The role of brand identification', Journa of Targeting, Measurement and Analysis for Marketing 18, 167-176. https://doi. org/10.1057/jt.2010.15

Lager, M., 2008, 'Fine-tuning the channel', Customer Relationship Management 1(1), 30-33.

Lundmark, M., 2017, 'Loyalty programs in a collegial sports context: Promoting student fan behaviour through rewards strategies', Master's thesis, Malmo University, Malmo.

Martin, D., O'Neill, M., Hubbard, S. \& Palmer, A., 2008, 'The role of emotions in explaining consumer satisfaction and future behavioural intention', Journal of Service Marketing 22, 224-236.

Martínez, J.A., Ko, Y.J. \& Martínez, L., 2010, 'An application of fuzzy logic to service quality research: A case of fitness service', Journal of Sport Management 24(5), 502-523. https://doi.org/10.1123/jsm.24.5.502

Mays, J., 2012, 'Fan loyalty and motivation', BA Thesis, University of Nevada, Las Vegas, NV.

Misener, K.E. \& Doherty, A., 2012, 'Connecting the community through sport club partnerships', International Journal of Sport Policy and Politics 4(2), 243-255. https://doi.org/10.1080/19406940.2012.674962

Mullin, B.J., Hardy, S. \& Sutton, W.A., 2007, Sport marketing, 3rd edn., Human Kinetics, Champaign, IL.

Nieuwenhuis, J., 2008, 'Introducing qualitative research', in K. Maree (ed.), First steps in research, Van Schaik Publishers, Pretoria. 
O’Reilly, N., Graham, T. \& Rennie, L., 2013, Branding and marketing in sport, 2nd edn., Pearson Education Limited, Harlow.

Ou, W.M., Shih, C.M., Chen, C.Y. \& Wang, K.C., 2011, 'Relationships among customer loyalty programs, service quality, relationship quality and quality: An empirical study', Chinese Management Studies 5(2), 194-206. https://doi.org/10.1108/ 17506141111142825

Premier Soccer League (PSL), 2011, Annual Financial Statement, Annual Report, viewed 20 August 2018, from www.psl.co.za.

Rahman, S., 2016, 'The advantages and disadvantages of using qualitative and quantitative approaches and methods in language "Testing and Assessment" Research', A Literature Review. Journal of Education and Learning 6(1), 102-112. https://doi.org/10.5539/jel.v6n1p102

Richelieu, A.S., Lopez, S. \& Desbordes, M., 2008, 'The internationalization of a sports team brand: The case of European soccer teams', International Journal of Sports Marketing \& Sponsorship 9(4), 2-44.

Roberts-Lombard, M., 2009, 'Customer relationships in the retail travel trade. What is the opinion of management?', Journal of Contemporary Management $6,409-429$.

Ruyruen, P. \& Miller, K.E., 2007, 'Relationship quality as a predictor of B2B customer loyalty', Journal of Business Research 60(1), 21-31. https://doi.org/10.1016/j. jbusres.2005.11.006

Samra, B. \& Wos, A., 2014, 'Consumer in sports: Fan typology analysis', Journal of Intercultural Management 6(4), 263-288. https://doi.org/10.2478/joim2014-0050

Schomburg, B., 2015, 'Spectator attendance strategies. A best practices examination of MLS expansions franchises', BSc, California Polytechnic State University, San Luis Obispo, CA.

Segalo, P., 2011, 'Our lives through embroidery: Narrative accounts of the women's embroidery project in post-apartheid South Africa', Journal of Psychology in Africa 21(2), 229-238. https://doi.org/10.1080/14330237.2011.10820451

Shank, M.D. 2005, Sports marketing: A strategic perspective, 3rd edn., Pearson Education, Upper Saddle River, NJ.

Shobian, M.S., 2012, 'Factors affecting spectators' decision in attending minor league baseball home games', BA, Alfaisal University, Riyadh.

Solberg, E.F., 2008, 'The contours, dynamics and impacts to African football migration to South Africa', MA Dissertation, Stellenbosch University, Stellenbosch.

Sport Industry Growth South Africa, 2012, Experts to debate South Africa's R7 Billion Sponsorship market (article was published on the 17th August 2012, viewed 20 August 2012, from http://www.sportindustry.co.za/feature/view/ 4694/Experts
Stander, F.W. \& Van Zyl, L.E., 2016, 'See you at the match: Motivation for sport consumption and intrinsic psychological reward of premier football league spectators in South Africa', SA Journal of Industrial Psychology/SA Tydskrif vir Bedryfsielkunde 42(1), a1312. https://doi.org/10.4102/sajip.v42i1.1312

Stavros, C., Pope, N. \& Winzar, H., 2008, 'Relationship marketing in Australian professional sport: An extension of the Shani framework', Sport Marketing Quarterly 17(3), 135-145.

Stolt, M., 2010, 'The demand for football attendance in Sweden', BA Dissertation, Stockholm University, Stockholm.

Tichaawa, T.M. \& Harilal, V., 2016, 'Golf tourism in South Africa: Profiling attendees at a major championship event', African Journal for Physical Activity and Health Sciences (AJPHES) 22(3:1), 795-807.

Toedt, M., 2014, 'A model for loyalty in the context of customer relationship marketing', European Scientific Journal 1(11), 229-236.

Van Heerden, C.H. \& Du Plessis, P.J., 2004, 'Analysis of Sport Sponsorship Management in South Africa - Implications for Africa', Africa Journal for Physical, Health Education, Recreation and Dance (AJPHERD) 10(1), 71-89.

Van Vuuren, T., Roberts-Lombard, M. \& Van Tonder, E., 2012, 'The relationship between selected variables and customer loyalty within an optometric practice environment', Acta Commercii 12(1), 94-106. https://doi.org/10.4102/ac.v12i1.137

Wann, D.L., Melnick, M., Russel, G. \& Pease, D., 2001, Sport fans: The psychology and social impact of spectators, Routledge, New York.

Wilkins, V., 2009, 'Understanding loyalty and motivation of professional sports fans', Bachelor's dissertation, Indiana University, Bloomington, IN.

Wilkins, V., 2012, 'Understanding loyalty and motivations of professional sport forms', Master's dissertation, University of Nevada, Las Vegas, NV.

Williams, J. \& Chinn, S.J., 2010, 'Meeting relationship-marketing goals through socia media: A conceptual model for sports marketers', International Journal of Sport Communication 3, 422-437.

Wu, S.H., Tsai, C.Y. \& Hung, C.C., 2012, 'Toward team or player? How trust, vicarious achievement motive, and identification affect fan loyalty', Journal of Sport Management 26, 177-191. https://doi.org/10.1123/jsm.26.2.177

Xu, O., 2015, 'Live spectators view on sponsorship in sporting events', MA, Gothenburg School of Business, Economics and Law, University of Gothenburg.

Yoshida, M. \& James, J.D., 2010, 'Customer satisfaction with game and service experiences: Antecedents and consequences', Journal of Sport Management 24(3), 338-361. https://doi.org/10.1123/jsm.24.3.338

Zhao, X., Hou, J. \& Gilbert, K., 2014, 'Measuring the variance of customer waiting time in service operations', Journal of Management Decision 52(2), 296-312. https:// doi.org/10.1108/MD-01-2013-0012 